\title{
Konsepsi Agama dan Seni Rupa dalam Rurub Kajang Tutuan (Kajian Estetika Hindu)
}

\author{
I Wayan Agus Gunada \\ Program Studi Pendidikan Agama Hindu, Fakultas Dharma Acarya \\ Institut Agama Hindu Negeri Gde Pudja Mataram. \\ Jalan Pancaka No. 7B, Mataram. 80326, Indonesia \\ gunadastahngpmataram@gmail.com
}

Penelitian ini bertujuan mengkaji keberadaan kajang sebagai bagian dari upakara pada prosesi ngaben di Bali. Kajang merupakan suatu kain yang berisikan aksara-aksara suci dan simbol-simbol yang memiliki makna filosofis keagamaan menurut Hindu. Kajang Tutuan merupakan suatu bentuk kajang yang digunakan dalam prosesi ngaben warga Tutuan. Bukan hanya sekedar sarana pelengkap upacara, namun terkandung simbol dan fungsi yang cukup penting yaitu identitas Tutuan sebagai bagian dari warga di Bali. Keberadaan kajang Tutuan tidak hanya sebagai bagian dari sarana keagamaan dalam upacara ngaben namun terkandung konsepsikonsepsi seni rupa dan agama Hindu yang saling berhubungan didalamnya. Penelitian kualitatif dengan studi pendekatan fenomenologis ini menggunakan teknik pengumpulan data berupa pengamatan, wawancara serta kajian pustaka yang relevan dengan fokus penelitian. Dari hasil penelitian ditemukan bahwa konsepsi agama dan seni dalam kajang Tutuan terbagi dalam tiga hal yaitu satyam, siwam dan sundaram. Satyam yaitu terdapat makna-makna filosofis dalam kajang Tutuan. Siwam bahwa dalam proses pembuatan dan penggunaan kajang terdapat ritual-ritual suci. Sundaram bahwa terdapat nilai-nilai keindahan dalam kajang Tutuan. Berdasarkan hasil analisis tersebut, diharapkan penelitian ini dapat berkontribusi, dan berdampak dalam memberikan sumbangsih pengetahuan. Penelitian ini juga dapat menjadi suatu pustaka dalam kajian terhadap sarana upacara agama Hindu.

Kata kunci: kajang, estetika, hindu, tutuan

\section{The Conception Of Religion And Fine Art In Rurub Kajang Tutuan (Hindu Aesthetic Studies)}

This research aims to examine the existence of Kajang as part of the upakara at the ngaben procession in Bali. Kajang is a cloth containing sacred characters and symbols that have religious, philosophical meanings according to Hinduism. Kajang Tutuan is a form of Kajang used in the procession ngaben Tutuan citizens who are not just a means of complementary ceremonies but contained symbols and functions that are pretty important, namely the identity of the Tutuan breed itself. Kajang Tutuan is not only part of the religious facilities in the ngaben ceremony but contains conceptions of fine art and Hinduism that are interconnected in it. Qualitative research with phenomenological approach studies uses data collection techniques in observations, interviews, and literature studies relevant to research. The study results found that the conception of religion and art in Kajang Tutuan is divided into three things, namely Satyam, siwam, and Sundaram. Satyam that there are philosophical meanings in Kajang Tutuan. Siwam that in the process of making and using Kajang, there are sacred rituals. Sundaram that there are values of beauty in Kajang Tutuan. Based on the results of the analysis, it is expected that this research can contribute and have an impact on contributing knowledge. This research can also be a library in the study of Hindu rituals.

Keywords: kajang, aesthetic, hinduism, tutuan

Proses Review : 1 - 20 Mei 2021, Dinyatakan Lolos: 31 Mei 2021 


\section{PENDAHULUAN}

Hindu merupakan agama mayoritas yang dianut oleh masyarakat Bali, Hindu bukan sekedar agama sebagai konsep keyakinan melakukan ritus agama pemujaan terhadap Tuhan namun lebih mendalam Hindu merupakan pandangan hidup dan Hindu merupakan cara hidup yang menjadi pondasi kehidupan masyarakat Bali, tidak hanya pada ritus keagamaan, namun pada sisi lain yang menjadi bagian dari kehidupan masyarakat Bali. Ini menandakan bahwa Hindu bukan sekedar agama yang didalamnya terdapat cara-cara dalam melaksanakan pemujaan kepada Tuhan, namun konsep ajarannya yang begitu universal menjadi suatu pandangan dan cara hidup bagi masyarakat Bali.

Pandangan dan cara hidup Hindu ini pun juga sangat mempengaruhi kehidupan berkesenian di Bali, pengaruh ini sangat terlihat dalam berbagai karya seni yang lahir dari para seniman-seniman Bali yang mengambil konsep ajaran agama Hindu, baik dari sisi ajaran-ajaran maupun cerita-cerita Hindu yang diwujudkan dalam berbagai karya seni. Seni Bali bukan sekedar kegiatan yang bertujuan untuk pemenuhan rasa keindahan semata, namun seni Bali lebih pada proses berkeagamaan Hindu. Terlihat dari pelaksanaan kesenian dalam proses ritual yadnya, misalnya pementasan tari sakral Topeng Sidakarya dalam upacara besar. Tari topeng Sidakarya merupakan tari sakral yang memiliki makna dan tujuan agar upacara berjalan lancar dan selamat terhindar dari segala mara bahaya (Dewi \& Wardana, 2018). Ini menandakan tari topeng Sidakarya sebagai sebuah karya seni yang sangat kental dengan nuansa keagamaan yang tentu dalam prosesnya selalau berdasarkan dan ditujukan untuk pelaksanaan yadnya.

Konsepsi agama dan seni dalam kehidupan masyarakat Bali menjadi sumber dari budaya Bali. August Comte dalam Haryanto (2015) menyebutkan bahwa agama merupakan perekat sosial yang mencegah perpecahan di masyarakat, sehingga agama sebagai bagian dari proses peningkatan solidaritas sosial (Haryanto, 2015). Seni menjadi bagian dari agama dalam peningkatan solidaritas sosial, terlihat dalam antusias masyarakat melihat pagelaran seni yang dipertunjukkan dalam ritual yadnya. Secara filosofis agama dalam beberapa literatur berasal dari bahasa Sanskerta, Nala dan Wiratmadja (2004) menjelaskan bahwa secara etimologi agama berasal dari bahasa sanskerta yang bermakna kedatangan, dan secara terminologis adalah sesuatu yang tidak pergi, kedatangan wahyu atau sabda suci abadi yaitu Tuhan (Nala \& Wiratmadja, 1991). Istilah agama pula adalah suatu peraturan yang menghindarkan manusia dari kekacauan dan membawa manusia pada kehidupan yang teratur (Asir, 2014).

Agama merupakan suatu pedoman yang berasal dari sabda suci Tuhan yang akan membawa manusia pada kehidupan yang lebih baik, tertib dan menghindarkan diri dari perbuatan-perbuatan yang tercela dan tidak baik. Agama dalam pandangan teoritis dan filosofis menurut Ghazali (2011) adalah seperangkat kepercayaan dan keyakinan, doktrin atau aturan mengikat dan norma-norma yang dianut dan diyakini kebenarannya oleh manusia sebagai landasan dan pedoman dalam kehidupannya (Ghazali, 2011). Kehidupan beragama Hindu di Bali sangat dipercaya dan menjadi pedoman dalam pelaksanaan kehidupan umatnya, kolaborasi agama dan seni menjadi daya tarik dalam pelaksanaan keagamaan. Ini terlihat dalam setiap proses keagamaan selalu identik dengan eksistensi seni yang ada dan mengiringi baik itu seni tari, seni karawitan, seni sastra bahkan seni rupa.

Ngaben dalam pitra yadnya menjadi satu dari sekian banyak bukti bahwa seni bagian dari kehidupan ritual Hindu di Bali. Ngaben secara konseptual merupakan ritual yang dilakukan untuk jenasah yang memiliki tujuan pengembalian segala unsur alam semesta dalam tubuh manusia melalui proses pembakaran mayat (Suprayoga et al., 2018). Ritual ngaben merupakan suatu prosesi pembakaran jenasah dan bertujuan untuk mengembalikan unsur Panca Maha Bhuta kepada sumbernya. Melalui ngaben ini diharapkan segala ikatan duniawi yang mengikat atma melalui badan wadag-nya dapat terlepas untuk mencapai alam sesuai dengan hasil karmanya. Selain makna yang begitu filosofis dalam pelaksanannya upacara ngaben selalu dilakukan melalui proses-proses dan terdapat sarana-sarana yang khas dan unik serta diiringi oleh karya-karya seni yang cukup sakral seperti bade, petulangan, gamelan angklung, kajang dan lain-lain.

Sistem kekerabatan di Bali memiliki kekhasan secara lahir dan batin yang disebut dengan istilah soroh yaitu suatu ikatan berdasarkan garis keturunan (Saraswati et al., 2016). Karena adanya soroh-soroh dalam sistem sosial masyarakat Bali ini menyebabkan adanya perbedaan pelaksanaan ngaben di Bali. Perbedaan ini bukan pada tata cara upacara, namun kepada upakara yang digunakan seperti Bade, Petulangan dan kajang. Begitu pula dalam trah warga Tutuan pada proses ngaben-nya menggunakan sarana yang berbeda karena adanya bhisama yang mengatur. Salah satu bentuk perbedaan dalam sarana yang ditemui dalam prosesi ngaben adalah penggunaan rurub Kajang.

Secara pragmatis penelitian mengenai kajang Tutuan ini bertujuan untuk menggali permasalahan mengenai esensi pemahaman berkaitan dengan rurub kajang yang memiliki dua dimensi yaitu dimensi sebagai media dalam sarana upakara yang bersifat suci dan sakral, dan dalam dimensi lain rurub kajang merupakan karya seni rupa atau merupakan karya seni lukis tradisional Bali.

Sehingga secara konseptual dalam sisi kerangka penelitian, maka bahasan dan kajian mengenai rurub kajang Tutuan ini terdiri atas dua konsep yaitu paradigma rurub kajang 
sebagai media dan sarana upacara keagamaan Hindu khususnya dalam Upacara Ngaben. Paradigma kedua adalah mendasarkan rurub kajang sebagai karya seni murni yang bersifat fungsional sebagai bagian dari hasil karya cipta seni lukis tradisional Bali yang bersifat sakral. Sehingga menarik kemudian menganalisisnya dari sudut pandang estetika Hindu sebagai filsafat keindahan dalam Hindu.

Penelitian ini merupakan penelitian lanjutan dari penelitian sebelumnya yang dilakukan oleh penulis dalam mengkaji keberadaan sarana upacara dalam prosesi ngaben warga Tutuan. Gunada (2017) dalam penelitian sebelumnya mengkaji tentang petulangan bawi srenggi sebagai sarana pembakaran jenasah (Gunada, 2017) dan pada penelitian ini mengkaji kajang yaitu kain berisikan aksara-aksara dan simbol suci. Kajang bukan hanya sekedar penutup selimut sebagai sarana upacara semata, namun lebih dalam bahwa terdapat simbol serta fungsi yang cukup penting sebagai identitas soroh Tutuan dalam sistem sosial kehidupan masyarakat Bali. Penelitian ini pula diharapkan berkontribusi dan berdampak penting dalam kajian-kajian terkait upacara dan agama Hindu di Bali serta memberikan sumbangsih pemikiran dalam membahas bentuk-bentuk kajang dalam proses ngaben kaitannya dengan agama dan Seni.

\section{METODE PENELITIAN}

Penelitian ini merupakan bentuk penelitian lanjutan peneliti terkait kajian sebelumnya. Secara umum penelitian ini mengkhususkan diri pada ruang lingkup kajian terhadap kajang Tutuan. Sehingga kajang Tutuan menjadi objek dan fokus penelitian. Penelitian yang digunakan adalah penelitian kualitatif dengan jenis pendekatan studi fenomenologis, dimana dalam proses ngaben di Bali selalu terdapat sarana kajang, bukan hanya sebagai upakara namun adanya keharusan pemakaian kajang dikarenakan bhisama kawitan dalam setiap soroh, begitupun dalam soroh Tutuan yang mengharuskan adanya kajang..

Untuk menggali data maka digunakan teknik observasi atau pengamatan terhadap rurub kajang Tutuan, dilanjutkan dengan metode wawancara dengan narasumber yang mengetahui keberadaan kajang tersebut dan terakhir adalah kajian pustaka dengan melakukan studi dan kajian terhadap pustaka-pustaka serta dokumen, gambar dan berkas-berkas yang relevan. Peneliti bertindak sebagai instrumen kunci, untuk mendapatkan data yang valid maka data-data yang didapatkan kemudian diolah dan dianalisis menggunakan teknik Miles dan Huberman yaitu reduksi data, penyajian dan verivikasi data, setelah itu menggunakan teknik trianggulasi sumber dan teknik pengumpulan data untuk mendapatkan data yang valid dan absah (Sugiyono, 2016). Dalam membedah rurub kajang Tutuan ini terkait dengan konsepsi agama dan seni yang terkandung didalamnya maka penulis menggunakan beberapa teori sebagai pisau bedah yaitu teori religi, teori simbol, teori fungsi, teori rasa dan teori estetika khususnya estetika Hindu.

\section{ANALISIS DAN INTERPRETASI DATA}

Penggunaan kajang dalam proses ngaben warga Tutuan tercantum dalam prasasti kawitan Tutuan yang terkutip dalam teks berikut:

"Pamargane I Tutuan wenang mabade tur matumpang pitu, mabandusa, muwang mapanca datu, marurub kajang"

Terjemahan bebasnya :

"Proses upacaranya I Tutuan dapat menggunakan Bade bertingkat tujuh, menggunakan Bandusa, dan Panca Datu, rurub kajang"

Penggunaan Kajang umumnya disebabkan karena adanya bhisama yang melatarbelakangi, bhisama merupakan sebuah petuah, aturan, anjuran yang diturunkan oleh leluhur kepada para pratisentananya, bhisama mengikat soroh dalam kaitan tertentu yang beberapa diantaranya jika dilanggar dipercaya akan menyebabkan hal yang tidak baik.

Kajang secara umum adalah suatu kain yang digunakan untuk menutup sawa atau jenasah pada saat akan dibakar dalam upacara ngaben, kain sebagai penutup jenasah tersebut didalamnya dilukis berbagai aksara suci dan berbagai simbol sakral, simbol yang ada sebagian besar berhubungan dengan sejarah dari soroh yang ada. Penggunaan kajang dalam ngaben dipercaya memiliki kekuatan gaib yang akan membantu perjalanan sang roh menuju alam sunia (Suweta, 2011). Ini menandakan bahwa kajang bukan hanya sekedar sarana upacara namun didalamnya terkandung keyakinan bahwa penggunaan kajang akan membawa suatu kemudahan dalam perjalanan roh untuk menuju alam setelah kematian.

Kepercayaan eskatologis Hindu bahwa proses kematian merupakan suatu hukum yang kekal bagi yang hidup. Istilah eskatologis dalam konteks keilmuan yaitu suatu ilmu dan pengetahuan yang membahas tentang kebangkitan, dalam proses kebangkitan ini kematian menjadi langkah awal bagi roh untuk melanjutkan kehidupannya diakhirat (Abdillah, 2016). Namun kematian dalam konsep Hindu adalah hukum alam, atman yang menjadi intisari kehidupan akan lepas dari badan wadag untuk mencapai alam sunia, perjalanan menuju alam setelah kematian akan didampingi dengan hasil karma, namun pencapaian terbesar yang diharapkan adalah tercapainya Moksa. Secara konseptual dalam kepercayaan Hindu Bali roh setelah lepas dari badan wadag-nya belum dapat melanjutkan perjalannya jika belum diupacarai, dan proses selanjutnya ditentukan melalui hasil karma selama hidup, lebih lanjut dijelaskan 


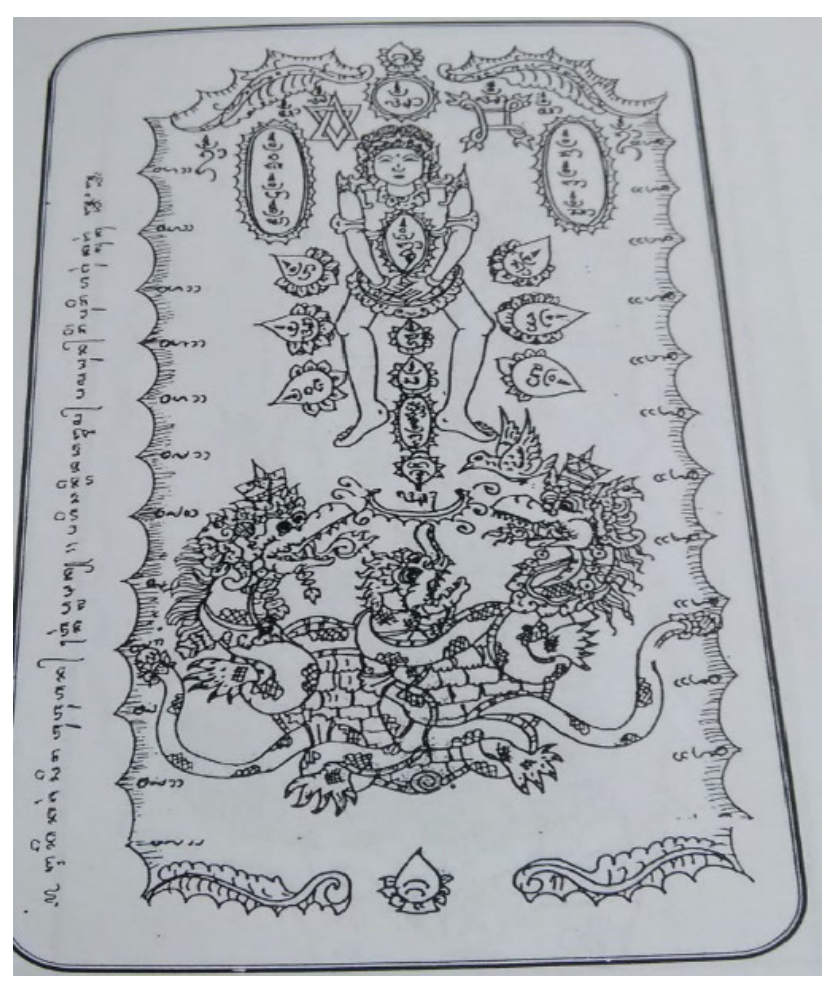

Gambar 1. Kajang Tutuan

(Sumber: Buku Alih Aksara Lan Teges Prasasti Ki Mantri Tutuan)

bahwa konsep moksa adalah keadaan dimana atma akan berada dalam alam Siwa untuk selamanya tanpa harus mengalami punarbhawa kembali (Mayuni et al., 2020).

Secara filosofis kajang adalah simbol wahana atman menuju brahman (Gentorang, 2016). Kajang sebagai simbolis wahana atman, bermakna simbol badan dari sawa yang akan diupacarai. Keberadaan kajang warga Tutuan, jika dilihat dari sudut pandang agama maka kajang sebagaimana yang disebutkan sebelumnya dan dari sudut pandang seni rupa maka kajang merupakan sebuah karya seni dua dimensi yang didalamnya berisikan unsurunsur kesenirupaan yaitu titik, garis, bidang warna, tekstur dan ruang yang juga mengandung prinsip-prinsip seperti kesatuan, irama, harmoni dan kontras. Konsep agama dan seni rupa begitu kental dalam rurub kajang warga Tutuan, penyatuan konsepsi ini terletak dari saling padunya antara agama sebagai roh dasar pembuatan dan penggunaan kajang, serta seni rupa sebagai media perwujudan kajang sebagai sarana agama sehingga bermuara dalam konsep estetika Hindu. Pengertian estetika sebagai suatu filsafat keindahan merupakan suatu pengalaman akan keindahan, baik keindahan jasmani maupun keindahan rohani (Surajiyo, 2015). Maka dalam kajang warga Tutuan ini konsepsi agama dan seni ditunjukkan melalui konsep estetika Hindu sebagai berikut :

\section{Konsepsi Satyam dalam Kajang Tutuan}

Estetika Hindu sebagai suatu kajian tentang pengalaman keindahan menurut agama Hindu dalam konsepsinya terdiri atas tiga hal utama yaitu satyam, siwam dan sundaram. Pada bagian pertama satyam memiliki posisi yang pertama karena dari satyam maka akan menimbulkan siwam, dan pertemuan antara satyam dan siwam yang akan memunculkan sundaram. Istilah satyam dalam estetika Hindu memiliki beragam pengertian. Secara pemaknaannya satyam sebagai salah satu konsep dalam estetika Hindu memiliki makna kebenaran dalam aspek keagamaan, artinya bahwa konsep kebenaran secara filosofis mendasarkan atas ajaran dan konsep-konsep keagamaan Hindu (Tirta, 2019)

Kajang Tutuan sebagai sarana selimut atau penutup jenasah bagi warga Tutuan didalamnya terdapat beberapa unsur yang membentuk kajang Tutuan. Secara struktur bahwa didalam kajang warga Tutuan ditemukan dua komponen besar yaitu bentuk-bentuk yang merupakan simbol tertentu serta aksara suci. Didalam kajang warga Tutuan terdapat simbol manusia, simbol naga dan badawang Nala, simbol padma, bunga, yantra bintang persegi enam, yantra persegi empat yang dimasing-masing sudut ber-lidah api, simbol burung, terdapat pula wijaksara mantram dasa aksara, panca aksara, panca brahma, tri aksara, dwi aksara dan eka aksara.

Simbol manusia dalam kajang tersebut memiliki makna dari sang diri sejati yaitu atman merupakan percikan kecil dari brahman yang menjadi intisari kehidupan manusia. Dalam proses ngaben, bertujuan untuk melepaskan ikatan atman dari badan wadag sehingga dengan membakar jenasah diharapkan ikatan atman terhadap badan kasarnya dapat dilepaskan. Simbol manusia dalam kajang warga Tutuan digambarkan tidak berjenis laki maupun perempuan sehingga yang memiliki makna atman dalam konsep Hindu memiliki sifat acintya yaitu tak terpikirkan. Sifat ini merupakan sifat dari brahman itu sendiri yang tidak dapat atau tidak terpikirkan bagaimana rupa, wujud dari Tuhan sehingga disimbolkan dengan Ardhanareswari.

Simbol memiliki arti penting dalam kebudayaan karena simbol merupakan representasi atau penyampaian ulang dari dunia dalam tataran filosofis (Agustianto, 2011). Simbol sebagai penyajian kembali bentuk alam atau dunia dalam sebuah gambaran. Naga dalam kajang Tutuan melambangkan Naga Ananthaboga dan Naga Basuki yang mengikat Badawang Nala. Konsep dua naga yang mengikat badawang nala memiliki makna menyatunya elemen tanah dan elemen air di bumi, sedangkan bedawang nala memiliki simbolisasi elemen api karena perwujudan bedawang nala yaitu penyu yang berapi (Paramadhyaksa, 2010). Maka makna simbol naga sebagai penyatuan elemen merupakan lambang kesuburan atau kesejahteraan, badawang nala yang disimboliskan sebagai elemen api juga merupakan bagian dari elemen kehidupan, melalui kajang terdapat doa dan harapan agar atma dari jenasah yang akan diupacarai dalam perjalanan menuju alam sunia yang diiringi oleh hasil karma selama 
hidup di dunia, sehingga pencapaian perjalanan adalah yang terbaik, maka konsep kesuburan dan kesejahteraan yang disimbolkan oleh naga merupakan harapan agar sang atma dapat mencapai surga dan menyatu dengan Brahman.

Bunga padma merupakan simbol alam semesta yang lahir dan muncul dari matahari yang merupakan lambang kesucian (Titib, 2003). Bunga padma secara filosofis merupakan tanaman yang hidup di lumpur kotor namun ketika berbunga memancarkan keindahan. Sehingga padma dalam kajang Tutuan merupakan simbol kesucian dari alam semesta Brahman itu sendiri. Manusia merupakan kreasi dari brahman yang didalam dirinya terdapat atman yaitu percikan kecil dari brahman, maka secara esensi manusia adalah suci sebagaimana brahman yang suci. Namun dalam hidupnya maka kesucian ini tentu akan dipengaruhi oleh berbagai sebab, sehingga kajang digunakan dan diharapkan untuk dapat menyucikan kembali atma agar dapat menyatu dengan brahman.

Simbol bintang segi enam dan persegi empat merupakan bagian dari yantra. Simbol bintang segi enam memiliki makna penyatuan atau bertemunya unsur purusa dan unsur prakerti sebagai unsur utama penciptaan, segitiga naik melambangkan purusa dan segitiga turun melambangkan prakerti, sedangkan bujur sangkar melambangkan unsur bumi (Titib, 2003). Kedua simbol ini memiliki makna bahwa alam semesta khususnya manusia tecipta melalui dua unsur utama yaitu purusa dan pradana, dimana pertemuan kedua unsur inilah yang menyebabkan terjadinya manusia dalam konteks penciptaan manusia dan alam semesta dalam konteks penciptaan dunia. Maka karena pertemuan dua unsur ini kemudian yang menyebabkan terjadinya suatu keberadaan di alam semesta namun ketika dua unsur ini tidak bertemu maka akan menyebabkan ketiadaan.

Simbol burung yang menjadi ciri dari kajang Tutuan memiliki makna tersendiri. Ini merupakan simbolisasi dari paksi tuhu-tuhu yang melambangkan jiwa dari Ni Brit Kuning ibu dari Ki Satryawangsa yang kelak menjadi Ki Mantri Tutuan. Diceritakan bahwa pada saat akan menyembah ibunya, Ni Brit Kuning tidak bersedia untuk disembah, lari dan terjatuh kedalam sumur, melihat hal tersebut Ki Satryawangsa kemudian melihat roh atau jiwa dari si Ibu kemudian meninggalkan tubuhnya dalam wujud Paksi Tuhu-tuhu dan raganya menjadi pohon timbul. Sehingga dalam bhisama Ki Mantri Tutuan bersumpah bahwa beliau dan seketurunannya berjanji seumur hidup tidak boleh memakan buah timbul dan tidak boleh mengganggu paksi tuhu-tuhu. Simbol burung atau paksi tuhu-tuhu ini meyimbolkan bahwa kajang Tutuan merupakan identitas dari warga Tutuan, dimana Ki Mantri Tutuan merupakan keturunan Dalem Mangori dan Ni Brit Kuning.

Aksara-aksara dalam kajang Tutuan terbagi dalam beberapa jenis namun semua aksara yang ada merupakan aksara suci yang hanya dipergunakan berkaitan dengan sesuatu hal yang sakral. keberadaan aksara Bali dalam kehidupan masyarakat Bali khususnya cukup berperan penting karena memiliki makna dan fungsi yang cukup beragam, dan didalam aksara-aksara tersebut terkandung nilai religius kaitannya dengan konteks beragama Hindu (Duija, 2017). Aksara-aksara suci dalam kajang Tutuan termasuk kedalam jenis aksara wijaksara. Aksara wijaksara sebagai salah satu klasifikasi aksara dalam bahasa Bali merupakan aksara suci yang hanya digunakan kaitannya dengan ritual keagamaan yang suci (Suwija, 2014). Penggunaan aksara wijaksara sebagai sebuah aksara suci tentu penggunaannya tidak sembarangan, umumnya digunakan pada hal-hal yang berkaitan dengan ritual dan sarana-sarana suci, kajang merupakan sarana yang digunakan pada upacara yadnya sehingga termasuk kedalam sarana yang suci.

Aksara Bali terutama aksara Modre sebagai aksara yang suci, sangat disucikan utamanya terkait dengan konteks penggunaan mantra-mantra dalam ritual Hindu (Parsua, 2018). Lebih lanjut disebutkan bahwa dasaksara merupakan sepuluh aksara suci yang jika disuarakan akan berbunyi sabatai nama siwaya merupakan doa untuk memuliakan Sang Hyang Siwa (Darsana, 2017). Hal ini mengindikasikan bahwa fungsi dan makna dalam aksara suci yang terdapat dalam kajang Tutuan berfungsi untuk menyucikan dan kesucian kajang dan sawa, karena dalam dasaksara berfungsi sebagai doa untuk memuliakan Dewa Siwa.

\section{Intisari Siwam dalam kajang Tutuan}

Konsepsi kedua dalam estetika Hindu terkait agama dan seni dalam kajang warga Tutuan adalah siwam. Istilah siwam memiliki makna kesucian dalam konteks keagamaan (Istanto, 2018). Perwujudan seni di Bali umumnya pada seni-seni tradisional yang digunakan pada saat mengiringi dan menjadi sarana ritual upacara dalam upaya seorang seniman mengekspresikan cipta, rasa dan karsanya melalui berbagai proses penyucian.

Umumnya penyucian berlangsung dari awal proses penciptaan karya hingga penggunaan karya, proses penyucian ini umumnya melalui dua metode yaitu melalui metode penggunaan sarana banten dan penyucian melalui laku kesucian diri seniman atau undagi. Laku kesucian dilakukan melalui proses menjaga perilaku selama proses penciptaan karya, maksudnya adalah pada saat melaksanakan penciptaan maka seorang seniman mengendalikan dirinya untuk selalu menjaga tutur katanya, perilakunya dan pikirannya atau dalam bahasa Bali diistilahkan dengan ngeret indrya dalam ajaran agama Hindu berdasarkan atas pada ajaran Tri Kaya Parisudha. Sehingga diharapkan melalui pengendalian diri tersebut karya yang tercipta yang akan digunakan sebagai sarana upacara menjadi suci sehingga tidak terpengaruh akan "kekotoran" dalam diri seniman. Penggunaan sarana banten 


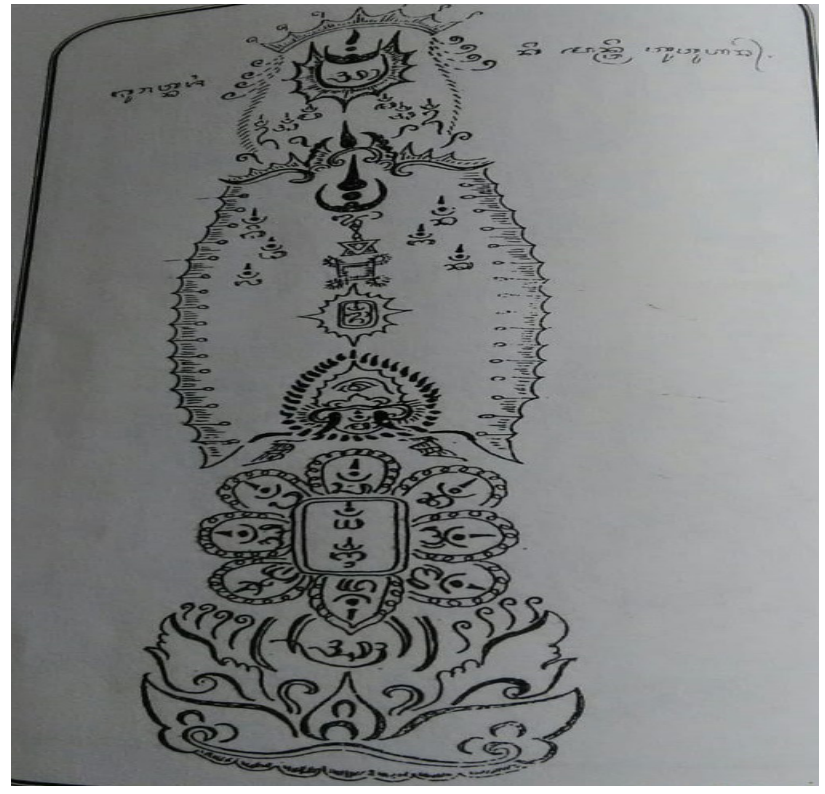

Gambar 2. Bentuk Gambar dan Aksara Surat Kajang Tutuan (Sumber: Buku Alih Aksara Lan Teges Prasasti Ki Mantri Tutuan)

umum dipergunakan sebagai media untuk memperoleh kesucian, penggunaan banten digunakan baik pada saat memulai proses penciptaan, selama dan ketika proses akhir penciptaan karya dilakukan untuk tetap menjaga kesucian dari karya atau sarana upacara yang dibuat.

Dasar seni dalam Hindu terdiri dari tiga prinsip yaitu satyam adalah kebenaran, siwam adalah kesucian dan kebajikan serta sundaram adalah keindahan (Widiantari, 2018). Dibia dalam (Sudibya et al., 2018) menyatakan bahwa berbagai bentuk kesenian dapat dijadikan persembahan kepada Tuhan yang memiliki sifat satyam (kebenaran), Siwam (Kesucian) dan Sundaram (Keindahan).

Kajang dalam ngaben di Bali memiliki makna sebagai simbol pemujaan kebesaran Tuhan dalam berbagai manifestasinya dan untuk memohon agar atman yang diupacarai dapat kembali menyatu dengan Tuhan (Suweta, 2011). Sebagai simbol pemujaan maka tentu sebuah sarana yang akan digunakan untuk memuja Tuhan harus suci, dalam kajang Tutuan kesucian ini melalui proses pembuatan dan proses penggunaan melalui beberapa proses penyucian baik melalui sarana banten dan kesucian dari pembuat kajang.

Berdasarkan sumber buku alih lontar dan prasasti Ki Mantri Tutuan Pratisentana Sira Dalem Mangori dan informasi dari narasumber disebutkan bahwa dalam proses nunas kajang maka wajib menghaturkan beberapa sarana banten pada beberapa pelinggih di Pura. Proses menghaturkan banten ini memiliki makna sebagai bentuk permohonan izin kepada ida bhatara kawitan agar diberikan keselamatan dan kelancaran dalam pelaksanaan upacara ngaben dan memohon anugerah agar pembuatan kajang dapat berlangsung dengan baik dan selamat dan kajang yang dibuat sebagai sarana ngaben memiliki nilai kesakralan dan kesucian.

Setelah proses pembuatan kajang maka prosesi penyucian selanjutnya adalah melaspas. Melaspas dalam upacara bertujuan untuk membersihkan kotoran-kotoran yang terjadi selama undagi mengerjakan sebuah bangunan (Windhu et al., 1985). Tidak dapat dipungkiri bahwa dalam proses melukis kajang oleh undagi ataupun mangku yang dipintakan untuk melukis kajang tentu terjadi hal yang bisa saja membuat leteh atau kotor kajang yang dibuat, kekotoran tersebut juga berlaku pada bahan yang digunakan. Sehingga melalui proses pemelaspasan maka segala kekotoran yang terjadi dalam bahan kajang dan proses pembuatan oleh undagi dapat dibersihkan sehingga menjadi suci sekala niskala sehingga pantas untuk digunakan sebagai upakara. Dalam proses pemelaspasan kajang Tutuan maka dilakukan dengan proses upacara pemelaspasan dengan sarana banten.

\section{Teori Rasa dalam Sundaram Kajang Tutuan}

Seni selalu diidentikkan dengan keindahan, walaupun makna antara seni dengan makna keindahan memiliki semacam perbedaan. Dalam proses penciptaan karya seni keindahan menjadi tujuan utama sebuah penciptaan, namun keindahan seringkali tidak selalu diidentikkan dengan karya seni.

Keindahan sangat diperlukan dalam kehidupan utamanya kebutuhan akan kerohanian, keindahan adalah sebuah energi yang akan menjadi media untuk mengobati sisi emosional dan spiritual manusia karena tidak terpenuhinya kehendak diri akan materi (Ratna, 2015). Oleh karenanya keindahan merupakan suatu kebutuhan, kebutuhan akan kehendak-kehendak yang menginginkan keindahan sebagai pemenuhan rasa emosial dan spiritual. Sehingga oleh sebagian besar individu pemenuhan akan rasa keindahan akan dilampiaskan melalui kesenian dan sebagian lainnya akan mengejar keindahan melalui pengalaman keindahan lain.

Istilah sundaram dalam estetika Hindu memiliki makna keindahan yang bukan hanya sekedar pemenuhan atas keindahan jasmani namun lebih kepada pemenuhan akan keindahan rohani karena dasar penciptaan keindahan dalam estetika Hindu adalah spiritualitas Hindu yaitu melalui landasan ngayah, sradha dan bhakti kepada Ida Sang Hyang Widhi Wasa yang akan menciptakan keadaan lango atau kelangen. Dalam konsepsi berkesenian khususnya kesenian Hindu menurut Karthadinata terdapat enam syarat yang harus dipenuhi sehingga suatu karya dianggap memiliki nilai keindahan yang terkandung didalamnya, keenam syarat ini disebut dengan sad angga yang terdiri atas rupabedha, sadrsya, pramana, wanikabangga, bhawa dan lawanya (Karthadinata, 2008). 
Pada kajang Tutuan konsep rupabheda yaitu pembedaan bentuk terlihat dalam begitu banyaknya bentuk-bentuk yang tergambar dalam kajang Tutuan, bentuk-bentuk ini merupakan simbol-simbol suci yang memiliki nilainilai tatwa dalam Hindu. Terdapat beberapa bentuk yang berbeda seperti adanya bentuk simbol manusia, simbolsimbol naga dan badawang nala, simbol burung, simbol padma, aksara-aksara suci, simbol bintang segi enam dan simbol persegi empat yang masing-masing simbol ini jika dillihat maka akan dapat dikenali oleh orang yang melihatnya dan menjadi ciri serta karakteristik yang khas dalam kajang Tutuan.

Konsepsi sadrsya menurut Karthadinata yaitu kesaman dalam penglihatan (Karthadinata, 2008), dalam kajang Tutuan ini sadrsya diartikan dalam kesatuan makna, bahwa perbedaan simbol-simbol yang menghiasi kajang Tutuan memiliki maknanya masing-masing namun dalam satu kesatuan bentuk dalam kajang, simbol-simbol ini memiliki satu makna yaitu identitas warga Tutuan dan merupakan sarana ngaben yang berfungsi sebagai bentuk doa dan harapan agar atman dapat kembali menyatu dengan sang paramatman.

Konsepsi selanjutnya yaitu pramana yang memiliki pengertian sebagai ukuran yang tepat (Karthadinata, 2008), dalam kajang Tutuan tidak terdapat ukuran-ukuran yang pasti seberapa besar ukuran pembuatan kajang, bahkan dalam prasasti kawitan Tutuan sendiri tidak tertulis berapa ukuran dari kajang tersebut namun umumnya penggunaan rurub kajang sebagai selimut atau kain penutup jenasah maka ukuran kajang akan menyesuaikan dan disesuaikan dengan sawa yang akan di upacarai.

Konsepsi wanikabangga memiliki makna penguraian warna (Karthadinata, 2008). Rurub kajang Tutuan sendiri dilukis dalam kain putih menggunakan tinta hitam, yang umumnya memiliki pewarnaan hitam dan putih. Warna hitam putih secara visual memiliki beberapa makna, dalam teori warna, hitam dan putih tergolong dalam warna netral yaitu warna-warna yang menetralkan keberadaaan dan intensitas warna lain. Konsep hitam putih di Bali umum terlihat dalam penggunaan kain poleng yaitu kain yang memiliki warna hitam putih dalam pola-pola persegi yang saling bertemu dimana pertemuan hitam dan putih ini akan menimbulkan warna baru yaitu abu-abu, dan konsep kain poleng sendiri merupakan bagian dari rwa bhineda. Konsep rwa bhineda dalam kain poleng memiliki makna dua unsur yang berbeda namun saling berkaitan dan beriringan dan selalu ada dalam konteks alam semesta (Dewanti \& Kameswari, 2019).

Konsepsi rwa bhineda yang memiliki dua unsur yang berbeda namun selalu beriringan ini merupakan bentuk dari fungsi keseimbangan dan keharmonisan alam semesta, dua sifat yang berbeda ini merupakan inti dari penciptaan yaitu unsur purusa dan pradana. Warna hitam dan putih memiliki maknanya masing-masing, warna hitam diasosikan dengan malam dan kematian sedangkan putih diasosiakan dengan sinar dan kemurnian (Monica \& Luzar, 2011). Dalam Hindu simbolis pewarnaan terlihat dalam dewata nawa sangga yaitu sembilan dewa yang merupakan penyangga alam semesta yang ber-sthana di sembilan penjuru mata angin yaitu Dewa Iswara bersthana di arah timur dengan warna putih, Dewa Maheswara bersthana di arah tenggara dengan warna merah dadu, Dewa Brahma bersthana di arah selatan dengan warna merah, Dewa Rudra bersthana di arah barat daya dengan warna jingga, Dewa Mahadewa bersthana di arah barat dengan warna kuning, Dewa Sangkara bersthana di arah barat laut dengan warna hijau, Dewa Wisnu bersthana di arah utara dengan warna Biru/Hijau dan Dewa Sambu bersthana di arah timur laut dengan warna abu-abu/ biru muda serta pusat dari semua arah adalah Dewa Siwa bersthana di tengah dengan warna brumbun atau pencampuran semua warna melebur menjadi satu.

Konsepsi keindahan Hindu yang kelima adalah Bhawa, dalam konsep estetika Hindu bhawa berasal dari bahasa sanskerta, secara sederhana bhawa merupakan suasana atau pancaran rasa.

"Bhawa merupakan sumber utama dari bangkitnya rasa, jika bhawa adalah sebab maka abhinaya adalah akibat dari bangkitnya rasa karena bhawa, bhawa terbagi atas tiga yaitu Vibhava keadaan situasi yang membangkitkan emosi, sthayibhava emosi dasar dan vyabhicaribhava yaitu keadaan emosi atau mental yang bersifat sementara sedangkan abhinaya terbagi atas dua yaitu anubhava yaitu ekspresi rasa yang dikehendaki hadir dan sattvikabhava yaitu emosi yang timbul secara spontan (Yasa, 2007)”.

Konsep bhawa sebagai sumber utama bangkitnya "rasa". Lebih lanjut disebutkan bahwa istilah "rasa" merupakan bagian dari psikologis atau sisi emosional manusia yang akan dipengaruhi oleh berbagai hal dan faktor, salah satunya adalah seni, dimana seni akan diwujudkan dalam berbagai bentuk karya dan media yang mengakibatkan munculnya sisi keindahan, pengaruh dan berbagai faktor inilah yang kemudian menimbulkan "rasa" (Noorwatha \& Wasista, 2019). Kajang Tutuan dalam konsep bhawa maka terdapat beberapa rasa dalam bagian sangarasa yang terkandung didalamnya. Konsep "rasa" akan menyebabkan terbentuknya suatu pengalaman dari sisi psikologis dan emosional yaitu pengalaman keindahan yang akan mengantarkan seorang individu mencapai sisi psikologis transendental (Noorwatha, 2018), beberapa "rasa" dalam kajang tutuan yaitu srnggara rasa dan santa rasa. Srnggara rasa yaitu rasa cinta dan kasih, dan santa rasa yaitu rasa damai (Yasa, 2007).

Dua rasa ini merupakan rasa yang dominan yang terkandung di dalam kajang Tutuan jika dirasakan dan dilihat secara visual. Konsep rasa asmara merupakan rasa 
bhawa yang terjadi karena adanya rasa peduli dan rasa kasih terhadap sanak keluarga yang meninggal sehingga dengan berbagai usaha dan upaya dilakukan untuk mewujudkan ngaben sebagai bentuk rasa bhakti kehadapan leluhur dengan memohon kajang sebagai permohonan agar atman dari jenasah keluarga yang meninggal dipermudah jalan menuju alam sunia dan berharap agar atman dapat bersatu dengan brahman pencipta alam semesta. Santa rasa adalah rasa damai yang terjadi setelah penggunaan kajang Tutuan dalam upacara ngaben sehingga muncul rasa damai karena kewajiban melaksanakan prosesi ngaben sebagai bentuk bhakti kepada leluhur dalam bagian pitra yadnya sudah dapat dilaksanakan. Lawanya sebagai daya pesona (Karthadinata, 2008), dalam kajang Tutuan dapat diartikan sebagai sebuah daya taksu yaitu suatu daya yang timbul karena adanya ketakjuban dan ketertarikan terhadap apa yang dilihat dalam hal ini kajang Tutuan. Istilah taksu dalam budaya Bali memiliki makna yang cukup beragam, taksu memiliki makna yaitu suatu landasan atau pedoman terkait aspek-aspek kualitas dalam menghasilkan suatu karya yang bermutu yang menimbulkan kesan-kesan tertentu (Nilotama, 2006).

Lebih lanjut Dibia dalam (Wirawan, 2018) menyebutkan bahwa taksu merupakan energi dan daya puncak untuk meningkatkan intelektualitas, dan makna taksu tidak hanya berfokus pada kesenian saja ataupun satu profesi, taksu merupakan daya yang ingin dihadirkan dan dimunculkan, kehadiran taksu sebagai sebuah energi dapat dirasa dan ditangkap melalui organ persepsi yaitu melalui kesan yang dialami oleh Panca Indera.

Istilah taksu diartikan sebagai kekuatan gaib yang memberikan kecerdasan, pengalaman-pengalaman spiritual dan keindahan serta keajaiban kepada seorang seniman ataupun individu penikmat seni untuk dapat menampilkan diri sehingga terjadi semacam penyatuan antara penampilan seorang seniman dengan masyarakat sebagai penikmat kesenian (Chaya, 2014). Proses penghadiran taksu melalui ritual-ritual suci umumnya dilakukan dengan sarana-sarana ritual yang dilakukan dengan memohon kepada Dewata-dewata untuk hadir dan memberikan anugerah daya taksu, Budaya Bali dalam sistem religinya yang masih kental akan ritual dan tradisi upacara menjadikan ritual keagamaan sebagai salah satu upaya dalam menghadirkan taksu. Dalam Kajang Tutuan taksu dapat dirasakan dan diterima ketika dilihat secara visual, daya taksu ini muncul melalui dua proses yaitu taksu yang hadir karena daya pesona oleh undagi yang melukis kajang Tutuan tersebut, daya pesona ini muncul karena undagi sudah sangat mahir dalam melukis kajang tersebut sehingga menghasilkan suatu karya kajang yang sangat berkualitas, kedua pembuatan kajang yang melalui pelaksanaan ritual dari awal hingga akhir dalam proses ngaben turut menguatkan daya pesona yang muncul, rasa takjub dan tertarik sekaligus ngeri dirasakan karena adanya daya pesona ini sebagai perwujudan taksu.

\section{SIMPULAN}

Konsepsi agama dan seni dalam kajang Tutuan sebagaimana yang sudah dijelaskan pada bagian hasil dan pembahasan dapat disimpulkan bahwa agama Hindu menjadi roh dalam setiap perilaku kehidupan masyarakat Bali dan Seni menjadi media dalam pelaksanaan ritual kegamaan di Bali. Begitu pula yang terkandung dalam kajang Tutuan, agama Hindu menjadi roh sumber dan pedoman dalam penciptaan dan penggunaan kajang, sedangkan seni rupa menjadi media penyampaian dan pelaksanaan ritual agama Hindu dalam proses ngaben. Simbol-simbol dan aksara-aksara suci yang terdapat dalam kajang memiliki makna yang sangat suci, dan sangat indah dilihat dari sisi estetikanya. Konsepsi satyam memberikan makna bahwa terdapat sejarah, makna dan fungsi yang sangat penting terhadap keberadaan Kajang Tutuan ini bagi warga Tutuan, Intisari Siwam bahwa sebagai sebuah karya seni rupa karya seni lukis kajang harus melalui proses-proses penyucian melalui berbagai sarana- sehingga dapat digunakan sebagai upakara dalam upacara ngaben, konsepsi sundaram sebagai keindahan seni dan keindahan agama memunculkan berbagai rasa dalam konsepsi teori rasa utamanya taksu sebagai daya pesona.

\section{UCAPAN TERIMA KASIH}

Terima kasih diucapkan kepada seluruh pihak yang telah membantu kelancaran seluruh proses penelitian, utamanya kepada seluruh narasumber yang berkenaan memberikan informasi berkaitan dengan proses penelitian. Tidak lupa ucapan terima kasih sebesar-besarnya juga kepada seluruh Warga Tutuan Pratisentana Dalem Mangori.

\section{DAFTAR RUJUKAN}

Abdillah. (2016). Eskatologi: Kematian dan Kemenjadian Manusia. Jaqfi: Jurnal Aqidah Dan Filsafat Islam, 1(1), 121-134. https://doi.org/10.15575/jaqfi.v1i1.1691

Agustianto A. (2011). Makna Simbol dalam Kebudayaan Manusia. Jurnal Ilmu Budaya, 8(1), 1-7. https://doi. org/10.31849/jib.v8i1.1017

Asir, A. (2014). Agama Dan Fungsinya Dalam Kehidupan Umat Manusia. AL ULUM : Jurnal Penelitian Dan Pemikiran Keislaman, 1(1), 50-58. https://doi. org/10.31102/alulum.1.1.2014.50-58

Chaya, I. N. (2014). Intensitas Budaya dalam Dunia Kepenarian. Panggung, 24(3), 295-307. https://doi. org/10.26742/panggung.v24i3.126

Darsana, I. N. (2017). Dasa aksara dalam bhuana alit (I. N. Darsana (ed.); 1st ed.). Universitas Udayana. http:// erepo.unud.ac.id/id/eprint/14116/1/18e87340e5003f26d5 924b16f7d9bd85.pdf 
Dewanti, P. P. W. A., \& Kameswari, I. G. A. A. W. (2019). Konsep Rwa Bhineda Pada Kain Poleng Busana Pemangku Pengluransaat Upacara Pengerebongan Di Pura Agung Petilan, Kesiman. Jurnal Da Moda, 1(1), 16-20. https://doi.org/10.35886/damoda.v1i1.52

Dewi, P. M. C., \& Wardana, I. P. P. (2018). Mengenal Sejarah dan Perkembangan Topeng Sidakarya. Acarya Pustaka: Jurnal Ilmiah Perpustakaan Dan Informasi, 5(1), 16-21. https://doi.org/10.23887/ap.v5i1.20788

Duija, I. N. (2017). Keberadaan Aksara Wrésastra Dalam Aksara Bali. Aksara, 29(1), 19-32. https://doi. org/10.29255/aksara.v29i1.98.19-32

Gentorang, I. M. A. (2016). Penggunaan Kajang Dalam Ritus Kematian (Kelepasan) Klen Brahmana Buddha Di Desa Budakeling Dan Sebarannya Di Desa Batuan (Kajian Antropologi Agama). Humanis, 15(3), 84-91. https://ojs. unud.ac.id/index.php/sastra/article/view/21861

Ghazali,A. M. (2011). Antropologi Agama (A. Saepulrohim (ed.); 1st ed.). ALFABETA.

Gunada, I. W. A. (2017). Patulangan Bawi Srenggi Dalam Prosesi Ngaben Warga Tutuan Di Desa Gunaksa, Kabupaten Klungkung (Kajian Estetika Hindu). Jurnal Penelitian AGama, 1(2), 17-21. https://doi.org/10.25078/ jpah.v1i2.210

Haryanto, S. (2015). Sosiologi Agama dari Klasik Hingga Postmodern (Andien (ed.); 1st ed.). Ar-Ruzz Media.

Istanto, R. (2018). Estetika Hindu Pada Perwujudan Ornamen Candi Di Jawa. Imaji: Jurnal Seni Dan Pendidikan Seni, 16(2), 155-161. https://doi.org/10.21831/ imaji.v16i2.22737

Karthadinata, D. M. (2008). Estetika Hindu Dalam Kesenian Bali. Imajinasi, 4(1), 1-17. http://journal.unnes. ac.id/nju/index.php/imajinasi/article/download/1428/1548

Mayuni, A. A. I., Yasa, I. W. S., \& Utama, I. W. B. (2020). Wacana Eskatologis Dalam Putru Pasaji. Dharmasmrti: Jurnal Ilmu Agama Dan Kebudayaan, 20(1), 10-18. https://doi.org/10.32795/ds.v20i1.636

Monica, \& Luzar, L. C. (2011). Efek Warna dalam Dunia Desain dan Periklanan. Humaniora, 2(2), 1084-1096. https://doi.org/10.21512/humaniora.v2i2.3158

Nala, I. G. N., \& Wiratmadja, I. G. K. A. (1991). Murddha Agama Hindu (1st ed.). PT. Upada Sastra.

Nilotama, S. K. L. (2006). Taksu Dalam Kebudayaan Bali. Dimensi, 4(1), 17-27. https://rijurnal.lemlit.trisakti.ac.id/ dimensi/article/view/1309/0
Noorwatha, I. K. D. (2018). Rekontekstualisasi Estetika Hindu 'Rasa' Dalam Desain Arsitektural. Mudra Jurnal Seni Budaya, 33(2), 200-208. https://doi.org/10.31091/ mudra.v33i2.351

Noorwatha, I. K. D., \& Wasista, I. P. U. (2019). Rasayatra: Eksplorasi Estetika Hindu 'Nawarasa' dalam Desain Interior Museum 3D Interactive Trick Art. Mudra Jurnal Seni Budaya, 34(2), 147-156. https://doi.org/10.31091/ mudra.v34i2.514

Paramadhyaksa, I. N. W. (2010). Makna Filosofis Keberadaan Ornamen Bedawang Nala Di Dasar Bangunan Meru. Jurnal Filsafat, 20(1), 45-55. https://doi. org/10.22146/jf.3432

Parsua, G. R. (2018). Aksara Dalam Tubuh Manusia Menurut Lokalitas Hindu di Bali. Vidya Samhita Jurnal Penelitian, 4(1), 34-40. https://ejournal.ihdn.ac.id/index. php/vs/article/view/697

Ratna, N. K. (2015). Estetika Sastra dan Budaya (1st ed.). Pustaka Pelajar.

Saraswati, D. R., Erviantono, T., \& Noak, P. A. (2016). Politik Organisasi MGPSSR Dalam Pilkada Serentak Kabupaten Karangasem Tahun 2015. E-Jurnal Politika, 1(1), 1-13. https://ojs.unud.ac.id/index.php/politika/ article/view/22195

Sudibya, I. G. N., Sukerta, P. M., Kusumo, S. W., \& Supriyanto, E. (2018). Fungsi dan Peran Api dalam Seni dan Kehidupan Masyarakat Bali. Panggung, 28(2), 200 214. https://doi.org/10.26742/panggung.v28i2.520

Sugiyono. (2016). Metode Penelitian Kuantitatif, kualitatif dan $R \& D$ (1st ed.). ALFABETA.

Suprayoga, K. A., Atmadja, A. T., \& Dewi, P. E. D. M. (2018). Mengungkap Praktik Penentuan Harga Bekal Sawa Pada Ngaben Masal Dalam Bingkai Kearifan Lokal Budaya Lek ( Studi Kasus Pada Dadia Arya Gajah Para Banyuatis , Desa Banyuatis Kecamatan Banjar Kabupaten Buleleng ). JIMAT (Jurnal Ilmiah Mahasiswa Akuntansi), 9(1), 45-54. https://doi.org/10.23887/jimat.v9i1.20432

Surajiyo. (2015). Keindahan Seni dalam Perspektif Filsafat. Jurnal Desain, 2(3), 157-168. https://doi. org/10.30998/jurnaldesain.v2i03.581

Suweta, I. M. (2011). Fungsi Dan Makna Aksara Simbol Pada Teks Kajang Dalam Ritual Ngaben Di Bali. Lingua : Jurnal Ilmu Bahasa Dan Sastra, 6(3), 249-252. https:// doi.org/10.18860/ling.v6i3.1466

Suwija, I. N. (2014). Pasang Aksara Bali (I. N. Suwija (ed.); 1st ed.). Pelawa Sari. 
Tirta, I. M. D. (2019). Konstruk Estetika Hindu dalam Realitas Seni di Bali. Jurnal Pangkaja, 22(1), 90-102. https://ejournal.ihdn.ac.id/index.php/PJAH/article/ view/1673

Titib, I. M. (2003). Teologi dan Simbol-Simbol dalam Agama Hindu (1st ed.). Paramita.

Widiantari, N. W. (2018). Spiritualitas Hindu Dalam Menari Dan Menata Tari. Sitakara: Jurnal Pendidikan Seni Dan Seni Budaya, 3(2), 1-7. https://doi.org/10.31851/ sitakara.v3i2.2337

Windhu, I. B. O., Ardana, D. P., Simpen AB, I. W., Taro, M., Wardana, P. N., Purnatha, P. M., Agastia, I. B. G., \& Ranuara, I. B. A. (1985). Bangunan Tradisional Bali Serta Fungsinya (I. G. B. N. Pandj, M. Bandem, B. N. Putra, G. W. Cidra, \& I. B. Raka (eds.); 1st ed.). Departemen Pendidikan dan Kebudayaan Direktorat Jenderal Kebudayaan Proyek Pengembangan Kesenian Bali. http://pustaka.kebudayaan.kemdikbud.go.id/index. php? $\mathrm{p}=$ show_detail\&id=858\&keywords $=$ bangunan + bali Wirawan, K. I. (2018). Taksu Dalam Dramatari Calonarang Sebuah Kajian Estetika Hindu. Widyadari, 19(1), 40-45. https://doi.org/10.5281/zenodo. 1240590

Yasa, I. W. S. (2007). Teori Rasa: Memahami Taksu, Ekspresi \& Metodenya (I. W. Teguh (ed.); 1st ed.). Program Magister Ilmu Agama dan kebudayaan Universitas Hindu Indonesia Denpasar. 